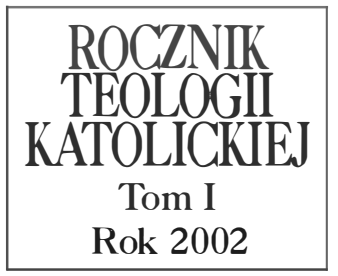

Ks. Tadeusz Kasabuła

Uniwersytet w Białymstoku

\title{
SPRAWOZDANIE Z SYMPOZJUM „DUCHOWOŚĆ CHRZEŚCIJAŃSKIEGO WSCHODU I ZACHODU" (25-26 STYCZNIA 2002 R.)
}

Wspólnym wysiłkiem organizacyjnym Katedry Teologii Katolickiej i Katedry Teologii Prawosławnej Uniwersytetu w Białymstoku odbyło się w Białymstoku - w dniu 25 stycznia 2002 r. w Centrum Kultury Prawosławnej przy ul. Św. Mikołaja oraz w dniu 26 stycznia 2002 r. w sali kina "Ton” przy Rynku Kościuszki - sympozjum poświęcone problematyce duchowości chrześcijańskiego Wschodu i chrześcijańskiego Zachodu. W pierwszym dniu obrad referaty wygłosili: ks. ihumen dr Paisjusz (Martyniuk) - Duchowość Wschodu, ks. prof. dr hab. Stanisław Urbański - Oblicze duchowości Kościota Zachodniego, ks. mgr Doroteusz Sawicki - Modlitwa Jezusowa $i$ jej wpływ na rozwój duchowości oraz dr Krzysztof Leśniewski, który próbował dać odpowiedź na pytanie: Czy duchowość prawostawna jest ekumeniczna $i$ otwarta.

Tej części sympozjum przewodniczył abp metropolita warszawsko-bielski i całej Polski prof. dr hab. Sawa, który otwierając obrady zauważył, że jest to pierwsze tego rodzaju spotkanie od II wojny światowej. Stwierdzenie to skorygował ks. bp Edward Ozorowski, podpowiadając, iż tego rodzaju spotkanie jest pierwszym „od stworzenia świata”. Abp Sawa nie do końca był przekonany, co do słuszności tej uwagi i próbował tłumaczyć, że już wcześniej miały miejsce "pewne spotkania”, które określił mianem „roboczych". Stwierdziwszy to, wyraził radość, że obie Katedry, pomimo różnych - jak stwierdził - obiektywnych trudności, mogły „coś podobnego zorganizować". Te trudności Arcybiskup złożył na karb ludzkich słabości, a ich przezwyciężenie przypisał Duchowi Świętemu, który, jak to określił, „działa i jest mądrzejszy od nas wszystkich tu razem wziętych". Przystępując do 
wprowadzenia w problematykę pierwszego dnia sympozjum, abp Sawa zacytował Pawła Ewdokimowa: „Wschód i Zachód są dzisiaj pojęciami geograficznymi. Prawda bowiem uwalnia się od wszelkich uwarunkowań i nawołuje do prawdziwego uniwersalizmu". Na tym stwierdzeniu oparł swe ogólnej natury rozważania nad duchowością Wschodu, obficie krasząc wypowiedź cytatami z dzieł Ojców Kościoła.

Ks. ihumen Paisjusz w pierwszej części swego obszernego wystąpienia podjął próbę zdefiniowania pojęcia duchowości w różnych jej aspektach, po czym postawił tezę, że ,prawosławna duchowość jest tak stara, jak stare jest chrześcijaństwo". Podkreślił, że duchowość prawosławna ma charakter wybitnie chrystocentryczny, ujmowana jest w aspekcie eschatologicznym i realizuje się w ascezie, którą określił jako logiczną konsekwencję owego chrystocentryzmu i wymiaru eschatologicznego duchowości Wschodu. Stąd - jego zdaniem - posiadała ona zawsze i posiada charakter wspólnotowy i społeczny. Twierdzenie to oparł głównie na treści listów św. Ignacego z Antiochii. Duchowość - kontynuował ks. Paisjusz - jest stanem trwania w łasce, chrześcijanin zaś, pozostając w pokorze ducha i w miłości do Chrystusa, wyraża ten stan w postawie modlitwy. Opierając się na tekstach wyjętych z dzieł Ojców Kościoła, prelegent doszedł do wniosku, że prawdziwym teologiem może być tylko ten, kto się modli, jako że nawet dogmaty definiowane przez sobory mają charakter doksologii, a wpisane w liturgię stanowią z nią organiczną całość. W tym kontekście, konkludując, określił modlitwę jako "oddech Ducha” i „barometr życia”.

Ks. prof. Urbański na wstępie swego wystąpienia zaznaczył, że problematykę duchowości Kościoła Zachodniego przedstawi w krótkim zarysie, nie sięgając do historii i tradycji. Prelegent stwierdził, że obecna dyskusja nad duchowością Zachodu wprowadza pewną rewolucję, która zmusza do powrotu do źródeł, do tradycji i do ponownego odkrywania podstawowych zasad, co pozwoli otworzyć drogę do odnowy chrześcijaństwa, stającego twarzą w twarz z kulturowymi wyzwaniami nadchodzącej epoki. Dzisiaj duchowość Zachodu to duchowość chrystocentryczna, sakramentalna, eklezjalna i personalistyczna, dotycząca głębi osobistych doświadczeń i otwarta na wszystko, co jest znaczące dla człowieka. Obecnie dostrzega się pilną potrzebę podjęcia dyskusji z nowymi odmianami religijności oraz nad tendencjami wypierania religii z życia Europy w tej epoce, którą określa się nierzadko mianem postsekularnej i w której mamy do czynienia z postmodernistyczną religijnością. Jest ona inspirowana pozachrześcijańskimi wartościami i tradycjami. Rodzi się nowa duchowość akulturowa i inkulturowa. Duchowość chrześcijańska musi się wcielić w kulturę, dokonać consecratio mundi poprzez twórcze działanie chrześcijanina. W ten sposób duchowość 
chrześcijańska, jako istotowo włączona w życie stworzonego świata, jest otwarta, wyzwolona z izolacji. Jest to „duchowość zanurzenia”, czyli włączenia w świat i w życie. Chodzi o to, by chrześcijanin pośród codziennych zajęć mógł realizować ideał świętości. Doświadczenie kontemplacji powinno przenikać aktywne życie społeczeństwa. Dzisiaj duchowość chrześcijańska nie może usunąć się na margines życia społecznego i pozostawać głucha na aktualne wezwania. Autor wyróżnił dwa typy duchowości: 1. Negatywny, reprezentowany przez tzw. intelektualistów wierzących, broniących wiary intelektualnej, nie doceniających zbyt mocno transcendencji, często sprowadzających pojęcie Boga do idei dyskutowania. 2. realizujący się w tzw. przebudzeniu religijnym o charakterze mistycznym, gdzie element doświadczalny przeważa nad intelektualnym. Dzisiaj obserwuje się zjawisko powrotu do mistyki. Wraz z powrotem do mistyki nastąpił powrót do doświadczenia modlitwy. Spowodowało to powstanie różnych środków modlitwy i odnowy jej charakteru wspólnotowego.

Reasumując, prelegent podkreślił, iż chrześcijanin Kościoła Zachodniego przeszedł transformację od religijności jako wierzenia, do religijności opartej na doświadczeniu Boga, które zrodziło duchowość personalistyczną, mistyczną, a jednocześnie duchowość prywatną i wspólnotową, pragnienie wyzwolenia się ze świata, w którym nie ma miejsca na poczucie bezinteresowności. Wszystko to tworzy ruch pragnący być Kościołem od dołu.

Ks. mgr Doroteusz Sawicki przedstawił ogólne przesłanki i refleksję nad tym, co Modlitwa Jezusowa („Panie Jezu Chryste, Synu Boży, zmiłuj się nade mną grzesznym") człowiekowi ofiarowuje, w jaki sposób kształtuje jego duchowość. "Choć tak skromna - stwierdził - zawiera wszystko, co powinno znaleźć się w modlitwie". W dalszej części referatu, snując refleksję nad modlitwą, w oparciu o teksty Ojców Kościoła, podjął próbę odpowiedzi na pytanie, czym jest modlitwa. Zauważył, że w przekonaniu pierwszych chrześcijan, sednem modlitwy jest jej ciągłość. Nieustanność jest też podstawowym założeniem praktykowania Modlitwy Jezusowej. Modlitwa ta powinna odznaczać się prostotą formy, połączoną ze skromnością materiału leksykalnego. Każdy wierny bez względu na wykształcenie, znajomość dogmatów i kościelnej praktyki może rozpocząć ćwiczenie Modlitwy Jezusowej. Prelegent podał też podstawowe wskazówki do praktykowania tej modlitwy i pokrótce scharakteryzował jej rozwój. Sumując tę część wykładu, ks. Sawicki zauważył, że w tej skondensowanej formie zawarta jest cała chrześcijańska prawda. Modlitwa Jezusowa jest Miniewangelią. To, co pisarze chrześcijańscy wykładali w dziesiątkach tomów, tu zawarto w jednym zdaniu. Drugą część wystąpienia prelegent poświęcił dość dokładnej analizie treści Modlitwy Jezusowej. 
Ks. dr Krzysztof Leśniewski swój referat rozpoczął od stwierdzenia, że to, co jest wspólne dla chrześcijańskiego Wschodu i chrześcijańskiego Zachodu, to fakt, że właściwie rozumiana duchowość jest rzeczywistością, która rodzi się z wiary w Boga w Trójcy Osób, a wyraża się świadczeniem jego obecności w życiu wierzącego trwającego we wspólnocie Kościoła. W ruchu ekumenicznym - kontynuował - coraz częściej dochodzi do głosu potrzeba określenia elementów, pierwiastków i podstaw duchowości składających się na duchowość wspólną, którą wszyscy chrześcijanie byliby w stanie zaakceptować. Określa się tą duchowość mianem „duchowości ekumenicznej”. Kościół zjednoczonego chrześcijaństwa musiałby być wszystko włączającym i powszechnym. Stąd aktualny postulat wypracowania duchowości integrującej, otwartej, która by zachowywała partykularną tożsamość danej tradycji religijnej, a z drugiej strony byłaby urzeczywistnieniem globalnego połączenia wielu ruchów odnowy wraz z szukaniem tego, co wspólne.

W przerwie (ok. 30 min.) zaprezentowano wystawę Duchowość Świętej Góry Atos.

W toku dyskusji abp Sawa, odnosząc się do referatu dra Leśniewskiego, stwierdził, że pojęcie „duchowość ekumeniczna” jest pojęciem pustym, bo - jak zauważył - „nie ma duchowości ekumenicznej i prędko nie będzie”, a jedność ma się dokonać w różnorodności.

Bp Jakub, nawiązując do referatu ks. prof. Urbańskiego, podjął problem wyobrażeń duchowych w życiu mistycznym i po dłuższym wywodzie wyartykułował pytanie: „w jakiej relacji pozostają zalecenia opata Antoniego Wielkiego nakazującego odrzucenie w medytacji wszelkich tzw. „wyobrażeń duchowych" do propozycji św. Ignacego Loyoli, nakazującego wręcz ich przywoływanie".

Ustosunkowując się do wątpliwości bpa Jakuba, prof. Urbański stwierdził, że pomiędzy mistyką Kościoła Zachodniego a mistyką Kościoła Wschodniego nie ma istotowej różnicy. Jeżeli istnieją różnice, to dotyczą one samej terminologii. Różnice dotyczą interpretacji, stąd inne rozumienie pojęcia „wyobrażenie” w mistyce wschodniej i zachodniej. Wg Ignacego Loyoli wyobrażenia nie są przeszkodą, przeszkodą może być wyobraźnia jako władza człowieka.

Ks. prof. Józef Zabielski, włączając się do dyskusji, wyznał, że oczekiwał sprecyzowania, dookreślenia, czym jest przedmiot życia duchowego, jako że jest to ciągle temat duskutowany. Zauważył też brak pewnych niezbędnych rozróżnień. Zapytał, czy można zgodzić się na rozróżnienie duchowości świeckiej i religijnej, w zależności od tego, jak człowiek pojmuje Boga. Ponieważ w chrześcijaństwie rozumiemy Boga tak samo, zatem rodzi się pytanie, co należy rozumieć pod pojęciem duchowości otwartej, o której 
mówił dr Leśniewski. Mówiąc bowiem o duchowości, jako relacji człowieka do Boga, to jest ona zawsze otwarta. Odnosząc się do referatu ks. Sawickiego, ks. Zabielski zapytał, jaką funkcję właściwie w Modlitwie Jezusowej pełni słowo i wskazał na pewną sprzeczność, jakiej dopuścił się - zdaniem dyskutanta - prelegent, który stwierdziwszy, że treścią tej modlitwy nie jest słowo, w tym samym zdaniu powiedział, że jej treścią jest właśnie „czynem poparte słowo".

Odpowiadając, ks. Leśniewski tłumaczył, że określenie „duchowość otwarta" jest pojęciem wypracowanym dla potrzeb ekumenizmu, dającym ekumenistom narzędzie, pozwalające na poszukiwanie tego, co chrześcijan łączy.

Prof. Jerzy Kopania podjął próbę ściślejszego logicznego usystematyzowania problematyki referatu ks. Sawickiego. Swoją wypowiedź skonkludował stwierdzeniem, że to, co stanowi o byciu teologiem, to wiedza i wiara, których zewnętrzną oznaką jest modlitwa.

Ks. Sawicki, ustosunkowując się do uwag ks. Zabielskiego, zauważył, że treścią modlitwy jest nie słowo, lecz życie ze wszystkimi jego elementami: czynem, słowem i myślą.

Pierwszy dzień sympozjum zakończył i podsumował abp Sawa.

Drugiemu dniu obrad przewodniczył ks. bp prof. dr hab. Edward Ozorowski. Tę część sympozjum wypełniły referaty ks. dr. Krzysztofa Nitkiewicza nt. Duchowość chrześcijańska w rozumieniu Stugi Bożego ks. Michata Sopoćki, ks. dr. Jerzego Tofiluka nt. Wptyw hezychazmu na rozwój duchowości oraz referat ks. abpa metropolity lubelskiego Józefa Życińskiego nt. Jakiej duchowości potrzebuje zjednoczona Europa? Tytułem wprowadzenia ks. bp Edward Ozorowski poczynił uwagę, że temat duchowości to temat ciągle żywy i aktualny, ponieważ od duchowości zależy życie człowieka. Dzisiejsze czasy nie sprzyjają rozwojowi duchowości, ponieważ istnieje w tym świecie wiele procesów, które niejako odczłowieczają, bo „człowiek dzisiaj to identyfikator, człowiek dziś traktowany jest komputerowo, człowiek dzisiejszy jest traktowany testowo - tym bardziej trzeba mówić o duchowości".

W pierwszym tego dnia referacie ks. dr Krzysztof Nitkiewicz rozpoczął swe wystąpienie od krótkiego nakreślenia biografii Sługi Bożego ks. Michała Sopoćki, przechodząc zaś do zasadniczej treści referatu podkreślił, że oryginalną cechą duchowości propagowanej przez ks. Sopoćkę jest przyznanie w niej centralnego miejsca idei Miłosierdzia Bożego, w którym Sługa Boży widzi podstawę życia duchowego. To właśnie w przyjęciu prawdy o Bożym Miłosierdziu znajduje się prawdziwy ratunek dla świata i dla każdego pojedynczego człowieka. Uważna lektura Pisma św. doprowadzi zawsze do wnio- 
sku, że w historii zbawienia Bóg jawi się jako Ojciec Miłosierdzia. Każdy, kto poznał prawdę o Bożym Miłosierdziu i doświadczył jego działania we własnym życiu, powinien być miłosierny względem bliźnich, dlatego że wszyscy są dziećmi jednego Ojca, który kocha każdego miłością miłosierną. Mówiąc o sytuacjach, w jakich winno być świadczone miłosierdzie, ks. Sopoćko odwołuje się do ośmiu błogosławieństw, które są miłosiernym drogowskazem dla każdego człowieka.

Kolejny prelegent, ks. dr Jerzy Tofiluk, na wstępie podkreślił konieczność określenia, czym jest hezychazm, ponieważ to pojęcie używane jest dzisiaj w różnych znaczeniach, bardzo bliskich sobie, nawzajem się przenikających, ale jednak różnych. Przedstawił następnie rozwój tego zjawiska w duchowości na przestrzeni wieków, koncentrując się na hezychazmie XIV w., który w dziedzinie metody praktykowania duchowości wyraża całe wielowiekowe doświadczenie wschodniego hezychazmu i mistyki wschodniej. Wskazał na dwa współistniejące ze sobą w hezychazmie etapy wstępowania do Boga: 1. Działanie (praxis), kiedy człowiek dąży do samokontroli i panowania nad namiętnościami i 2. Kontemplacja Bożej obecności w stworzeniu (theoria) i mistyczna kontemplacja Boga (theologia). Jego zwieńczeniem jest taki stan ducha, w którym dusza wyzwolona $z$ wszelkich więzów, wyciszona, niczego nie pragnie, jak tylko Boga (apatheia). Poddając analizie hezychazm XIV-wieczny, ks. Tofiluk podkreślił rolę nieustannej modlitwy wewnętrznej przy zastosowaniu określonych ćwiczeń ascetycznych, prowadzących do stanu wyciszenia. Hezychaści - mówił prelegent - mocno akcentowali transcendencję Boga, twierdząc, że nawet zbawienie nie daje możliwości widzenia i poznania istoty Boga. Ten apofatyzm widać w twórczości Grzegorza Palamasa. Bóg nie jest niczym z tego, co poznaje rozum ludzki i dlatego rozum ludzki może rozważać Boga tylko w kategoriach apofatycznych, poprzez użycie form negatywnych i wykluczających, zaś utożsamianie Boga z czymkolwiek innym jest pewnego rodzaju pogaństwem i czczeniem stworzenia bardziej niż Stworzyciela. Nawet wchodząc w kontakt ze stworzeniem, Stwórca pozostaje niedostępny stworzeniu. Mimo to hezychaści byli świadomi możliwości kontaktu z Bogiem, ponieważ człowiek jest zdolny do wyjścia ze stworzonego bytu poprzez posiadanie obrazu i podobieństwa Bożego, dlatego transcendencja Boga nie jest przeszkodą dla zjednoczenia z Nim.

Kończąc swoje wystąpienie, ks. Tofiluk zgodził się ze stwierdzeniem, że hezychazm od początku do dzisiaj pozostaje fenomenem ogólnoprawosławnej duchowości i kultury. Miał ogromny wpływ na rozwój monastycyzmu na Wschodzie. Teologia świata prawosławnego i jego duchowość zostały ukształtowane przez hezychazm. 
Ks. abp Józef Życiński zaczął od ogólnej uwagi, że nie można administracyjnie narzucić Europie jednej formy duchowości. Nie będzie też jednej konkretnej propozycji duchowości dla całej Europy, będzie natomiast jeden zbór wartości, które są istotne w przyszłym rozwoju kontynentu, i od których obecności także w trzecim tysiącleciu zależy duchowy kształt kultury europejskiej. Podstawowa troska chrześcijanina o jedność Europy to troska o obecność wartości duchowych w kulturze europejskiej, w której zachodzą tak głębokie zmiany. Wśród tych wartości abp Życiński na pierwszym miejscu postawił godność człowieka. Tym, co jest bezwzględnie konieczne w interpersonalnej relacji Bóg - człowiek, jest modlitwa. Nie mogą jej zastąpić żadne inne inicjatywy. Potrzebna jest modlitewna więź sakramentalna, eucharystyczna, medytacyjna. Nie należy bać się nowych form duchowości i nowych wyzwań w dziedzinie pobożności. Nasza cywilizacja ciągle jeszcze będzie stawiać wiele pytań, na które dzisiaj nie widać jednoznacznych odpowiedzi. Dlatego potrzeba Europie tej duchowości, która jest duchowością personalizmu, ukierunkowaną ku innym osobom. Konieczną cechą duchowości przyszłej Europy jest obecność refleksji racjonalnej. W kulturze, w której krzyk, demagogia i populizm staje się czynnikiem dominującym, należy dowartościować rolę etycznej refleksji, umieć jednoczyć tę refleksję z podejściem kontemplacyjnym.

W toku dyskusji abp Sawa, na kanwie wypowiedzi abpa Życińskiego, tytułem refleksji, postawił pytanie: „co stało się w Europie, którą przez tyle wieków tworzyli chrześcijanie, że należy na nowo przeprowadzać ewangelizację". Odpowiadając na tak postawione pytanie, abp Sawa stwierdził, że jest to skutek zaniedbania gorliwości, chęci pracy i modlitwy przez samych chrześcijan. Tymczasem wezwanie ora et labora dotyczy wszystkich, nie tylko „wybrańców”. Chrześcijaństwo zachodnie i wschodnie jest chore. „Ekumenizm jest taką chęcią wypracowania czegoś, co zatraciliśmy, a czym chcemy ubogacać" - zauważył Arcybiskup.

Ks. Zabielski, włączając się do dyskusji i zarazem odnosząc się do referatu ks. Tofiluka, postawił pytanie: czy istnieje analogia pomiędzy pojęciem postawy apatii w hezychazmie, a stoickim pojęciem apatheia. Zauważył też, że w wypowiedzi prelegenta zabrakło analizy pojmowania Boga, stąd pytanie, czy w tej drodze do poznania Boga, jaką proponuje hezychazm, istnieje pojęcie Boga jako osoby. Nawiązując natomiast do wypowiedzi abpa Życińskiego, ks. Zabielski zauważył, że mówiąc o wartościach stricte duchowych, można mówić tylko o jednej wartości, którą jest świętość. Inne duchowymi nie są. Przedmiotem życia duchowego nie są wartości, ale Bóg. Duchowość jest wszak czymś wyżej stojącym niż wartości.

Ks. Lewicki, nawiązując do referatu ks. Tofiluka, przypomniał, że pole- 
mika wokół hezychazmu w dziedzinie poznania Boga miała w dużej mierze odniesienie do nauki św. Tomasza, który wszak twierdzi, że mamy jakąś wiedzę pozytywną o Stwórcy.

Abp Życiński, odnosząc się do wypowiedzi ks. Zabielskiego, doprecyzował treść swego referatu, twierdząc, że nie uznał za konieczne i istotne dla merytorycznej strony wykładu stosowania proponowanych przez dyskutanta rozróżnień. Starał się natomiast zastosować tę procedurę, jaką Chrystus stosował, gdy określał kim są błogosławieni, gdzie świętość jest zdefiniowana w kategoriach wartości sprawiedliwości i pokoju. „Skoro Panu Jezusowi to uszło, to mam nadzieję, że i mi wybaczycie" - skonkludował.

Ks. Tofiluk, odpowiadając na wątpliwości ks. Zabielskiego, zauważył, że hezychazm bardzo mocno akcentuje kontakt człowieka - jako osoby, z Bogiem - jako osobą. Jest to kontakt absolutnie osobowy. Hezychazm mówi o udziale Trzech Osób Trójcy Świętej w dziele przebóstwienia ( Triady św. Grzegorza Palamasa). Co do pojęcia „apatia”, ks. Tofiluk wyjaśnił, że wprawdzie jego brzmienie w hezychazmie i u stoików jest takie samo, to jednak ich zakres semantyczny jest inny, bo inny jest cel tych dwóch postaw. Jest to „beznamiętność”, ale w chrześcijaństwie jest ona wprzęgnięta w służbę Bogu.

Poproszony przez prowadzącego sesję o zakończenie obrad i modlitwę końcową, metropolita białostocki abp Wojciech Ziemba stwierdził, że w Tygodniu Modlitw o Jedność Chrześcijan pragniemy rozpoznać siebie w kontakcie $\mathrm{z}$ Bogiem, chociaż jest to modlitwa prowadzona także w kontakcie z różnymi wyznaniami. Kończące się sympozjum nadało szczególny charakter tej modlitwie. Dzięki zasłyszanym treściom poczyniliśmy pomocną we wzajemnym poznawaniu się refleksję nad duchowością, odkryliśmy, że te dwie odmiany duchowości, Wschodu i Zachodu, wyrastają z jednego źródła. Zdumiewające jest - stwierdził Arcybiskup - że te dwie tradycje, rozwijające się przez wieki obok siebie, w tym co najbardziej istotne nie są skierowane przeciwko sobie. Kierownikom Katedr: abpowi Sawie i bpowi Edwardowi Ozorowskiemu, Metropolita Białostocki pogratulował tak trafnej inicjatywy, a za trud włożony w zorganizowanie sympozjum wyraził wdzięczność. Pogratulował też obecnemu na sali Rektorowi UwB, że uczelnia, którą kieruje, posiada takie instytucje jak Katedra Teologii Katolickiej i Katedra Teologii Prawosławnej. Wyrastają one ze wspólnej kultury i tradycji oraz są niezbędne, aby z szacunkiem patrzeć na człowieka, są też niezbędne, aby dobrze rozumieć cywilizację, określać teraźniejszość i formułować perspektywy na przyszłość. Wspólną modlitwą zakończono obrady. 